\title{
THE FINANCIAL SITUATION OF RURAL COMMUNES AND THE LEVEL OF THEIR INCOME IN THE ŚWIĘTOKRZYSKIE VOIVODSHIP
}

\author{
Paweł Dziekański ${ }^{1}$, Adrian Lipa ${ }^{2}$
}

\begin{abstract}
The commune's process of development (its development) takes place in a space that is completely filled by the natural and economic environment with their individual characteristics. Income and expenditure instruments, which are the basis for the operation of local government units and a condition for carrying out the tasks imposed on them, determine the scope and effectiveness of the impact of local government on local and regional development. The aim of the article is to analyse the spatial disproportions of the financial situation in relation to their income using a synthetic measure. The analysis was made in the system of 69 rural communes of the Świętokrzyskie province. As source material, data from the Regional Accounting Chamber and Local Database of the Central Statistical Office for 2007, 2014, and 2017 were used. Local government can carry out its tasks when it is equipped with stable and efficient sources of own income. Therefore, finance is the basis for the implementation of public tasks and determines the conditions for local economic development. The indicated areas are characterized primarily by traditional agricultural functions. In 2007, the financial standing measure (TOPSIS) ranged from 0.31 to 0.47 , in 2017 from 0.30 to 0.51 . In 2007, the financial standing (OE) measure ranged from 0.64 to 0.80 , in 2017 from 0.56 to 0.80 . Areas with a high level of financial standing were located mainly in the central area of the region (Sitkówka-Nowiny, Masłów, Strawczyn, Zagnańsk, Solec-Zdrój). The factors determining group membership were favourable location rent, a very good financial situation, and good infrastructure. Group entities are characterized by the highest average share of own revenues, as well as local taxes and fees in total revenues. At the other extreme of the distribution were areas with a low level of financial standing, which can be described as peripheral (Klimontów, Pawłów, Radoszyce, Bieliny, Dwikozy, Iwaniska, Bliżyn). This peripherality has a geographical dimension, expressed by its location relative to the centre of the region, as well as an economic and well-developed agricultural function.
\end{abstract}

Key words: financial situation, competitiveness, rural communes, synthetic measure.

JEL Classification: C38, H71, H76, B41, R10, P25

\section{Introduction}

Today, communes have become the subjects of economic processes. They pursue the interests of given communities, taking into account local resources. Their actions depend on both endogenous and exogenous factors. The commune's process of activity takes place in a space that is entirely filled by the natural and economic environment, and its specific, individual features of the economy, society, and resources (Rynio, 2013). Income and expenditure instruments determine the scope and effectiveness of the impact of local government on the local and regionaldevelopment. Theymaybeheldbylocal authorities depending on the division of competences and powers between the general government and local government institutions (Patrzałek, 2010).

\footnotetext{
Corresponding author:

${ }^{1}$ Jan Kochanowski University in Kielce, Poland.

E-mail: pdziekan@interia.eu

ORCID: https://orcid.org/0000-0003-4065-0043

${ }^{2}$ Scientific and Research Consortium, Poland.
}

They form a network of interrelationships and, acting for the benefit of the community, are interdependent and should be considered together (ZakrzewskaPółtorak, 2011). Municipalities are a place of concentration of economic activity. They also play the role of service, educational and industrial centres, generating a network of social and economic connections. Each commune has different endogenous resources (natural, economic, infrastructural) that shape conditions and development opportunities. They determine its attractiveness, form the basis of the development process, and affect the financial situation (Poczta, 2012; Dziekański, Shaposhnykov, 2017).

The activities of each commune involve the acquisition and expenditure of public funds. 
Therefore, it is important that systematic analyses of the management of these funds are carried out by local government bodies. Financial resources are the basis for the operation of local government units and a condition for carrying out the tasks imposed on them. They determine the development of the commune. Through the prism of finance, you can make a comprehensive assessment of the functioning of the commune and its development opportunities (Klepacki, Kusto).

The financial situation of the commune is closely correlated with the level of local development. It is a complex phenomenon. Provides the entity with the ability to perform tasks or increase assets. It is shaped by, among others, own income, income from taxes and local fees, investment expenditure, financial independence (Sobczyk, 2010). The financial situation is, therefore, directly related to access to sources of financial power and largely conditioned by the possession of stable and adequate sources of income (Głowicka-Wołoszyn, Wysocki, 2016). It determines the ability to implement actions intended by municipalities, which relate to the current needs of local communities and take developmental actions (Satoła, 2015).

\section{Purpose, method, scope of the study}

The aim of the article is to analyse the spatial disproportions of the financial situation in relation to their own income using a synthetic measure. Attempts were made to indicate the spatial distribution of the level of the financial situation of rural communes in the Świętokrzyskie voivodship. Which elements of the financial situation of rural communes explain its level the most? The analysis was made in the system of 69 rural communes of the Świętokrzyskie province. As source material, data from the Regional Accounting Chamber (Kielce branch) and Local Database of the Central Statistical Office for 2007, 2014, and 2017 were used.

On the first stage of the analysis, variables were selected in accordance with substantive usefulness in assessing the phenomenon under study, and the degree of variability and correlation of variables (Kukula, 2014). From the set of variables, those characterized by low spatial variability (variability index) and high correlation of variables (according to the inverted matrix method) were removed (Wysocki, Lira, 2005; Wysocki, 2010).

In the case of taxonomic methods, it is important to determine the nature of the variables describing the financial situation. Depending on the influence of variables on the studied phenomenon, stimulants and destimulants are distinguished ${ }^{1}$. The selected variables were subjected to the procedure of zero unitarisation using the following formulas:

$$
\begin{aligned}
& \text { for stimulants } z_{i j}=\frac{\mathrm{x}_{i j}-\min _{i} x_{i j}}{\max _{i} x_{i j}-\min _{i} x_{i j}} \text { when } x_{i} \in S \\
& \text { for destimulants } z_{i j}=\frac{\max _{i} x_{i j}-x_{i j}}{\max _{i} x_{i j}-\min _{i} x_{i j}} \text { when } x_{i} \in D
\end{aligned}
$$

where: $S$ - stimulant, $D$ - destimulant; $i=1,2 \ldots n$; $\mathrm{j}=1,2 \ldots \mathrm{n}, \mathrm{x}_{\mathrm{ij}}-$ means the value of the $\mathrm{j}-\mathrm{t}$ feature for the examined unit, max - the maximum value of the $\mathrm{j}$-t feature, min - the minimum value of the $\mathrm{j}$-t feature (Dziekański, 2017; Młodak, 2006).

Using the distance of each element of the object from the pattern and anti-pattern, Euclidean distances of individual objects from the pattern and anti-pattern were calculated according to the formula:

$$
\begin{aligned}
& d_{i}^{+}=\sqrt{\frac{1}{n} \sum_{j=1}^{m}\left(z_{i j}-z_{j}^{+}\right)^{2}}(3), \\
& d_{i}^{-}=\sqrt{\frac{1}{n} \sum_{j=1}^{m}\left(z_{i j}-z_{j}^{-}\right)^{2}}(4),
\end{aligned}
$$

where $\mathrm{n}-$ is the number of variables making up the pattern or anti-pattern, $z_{i j}$ - is the value of the uniformized feature for the tested unit (Wysocki, 2010; Zalewski, 2012).

On the next stage, the values of the synthetic feature were calculated according to the TOPSIS method for individual objects based on the formula:

$$
q_{i}=\frac{d_{i}^{-}}{d_{i}^{-}+d_{i}^{+}} \text {, when } 0 \leq q_{i} \leq 1, i=1,2, \ldots, n ; \mathrm{qi} \in[0 ; 1] \text {; }
$$

whereby: $d_{i}^{-}$means the distance of the object from the anti-template (from 0 ), $d_{i}^{+}$means the distance of the object from the template (from 1 ). Higher values of the qi measure indicate a more favourable financial situation of the commune (Euczak, Wysocki, 2012).

Then, a synthetic measure based on distance in real space was calculated with Euclidean metric according to the formula:

$$
O E_{i t}=\sqrt{\frac{1}{p} \sum_{j=1}^{p}\left(1-z_{i j t}\right)^{2}}(6) \text {, }
$$

where $i=1,2 \ldots N ; j=1,2 \ldots, p(N$ is the number of communal facilities, $p$ - number of features), $z_{i j}$ - means the value of the $j$-t feature for the given unit (Wysocki, 1996). The synthetic measure (6) allows measuring reduced to the range $[0 ; 1]$. A measure value of 0 means the maximum positive value of each of the units tested (Trojak, Tokarski, 2013).

In order to interpret the obtained measures, the division into quartile groups was used, where the size of the indicator in the first group means a better unit and the lower the group, the units are weaker. The mutual compatibility of the obtained results was also verified based on the correlation coefficient and regression analysis (Dziekański, 2016; Dziekański, Pawlik, 2019).

\footnotetext{
${ }^{1}$ The variables were removed due to the stability of the variables, the low value of the coefficient of variation below 0.10 . The inverse correlation matrix shows diagonal values below 10. According to the inverted correlation coefficient matrix method, diagonal elements (over-correlated variables) with values greater than 10 are eliminated from the set of variables (Malina, 2004).
} 


\section{The financial situation of communes (selected issues)}

Development is an ambiguous and complex concept; it results from the multitude of goals it serves and the variety of activities that shape it. Development is a set of changes aimed at increasing the satisfaction of collective and individual needs of local residents (Rosner, Stanny, 2014, 33). It is a multidimensional process, which involves transforming the factors and resources of the individual into goods and services for the local economy. It is controlled and modified by local authorities. To this end, using endogenous factors: finance, labour, technology, information, and others (Prusek, Kudełko, 2009).

The multidimensional functioning of local government units is demonstrated by the directions of action and the benefits achieved in the spatial, social, economic aspect, etc. These activities are usually focused on goals, among which should be distinguished long-term development, increase in income of residents and the budget, development of entrepreneurship (Dziekański, 2018).

The analyses conducted by Churski and co-authors (2013) and Stanny (2013) show that one of the important development factors is local finances. As Hendrick (2004) points out, the financial situation cannot be described in one-dimensional space (one indicator). It indicates the local government's ability to timely fulfil its financial obligations and ensure continuity in providing services to the local community. The value of a commune's financial standing can be used as a tool to study how various factors affect it, what its financial policy looks like. Douglas and Gaddie (2002) relate the financial situation to the ability to timely meet financial obligations and ensure continuity in the provision of services to the local community. Ritonga (2014) proposes a broad approach to measuring the financial situation of local governments, based on indicators grouped into six dimensions: short-term solvency, long-term solvency, budgetary solvency, financial independence, financial flexibility, and solvency at the level of services.

The financial situation of a territorial unit is a component of competitiveness and responsibility of local authorities for the development of the commune and meeting the needs of its inhabitants. The financial situation of the commune is closely correlated with the level of local development, understood as a complex of quantitative and qualitative transformations in a given commune, referring to the living standards of residents and the functioning of economic entities within the commune (Sobczyk, 2010; Kopyściański, Rólczyński, 2014). The financial situation of the commune is the state of its finances within a specified period of time. Its level is demonstrated by, among others ability to achieve a budget balance or increase in the commune's assets, level of commune income, financial independence of the unit, amount of investment expenditure, ability to obtain external financial resources, the financial result achieved by the commune (Ossowska, Ziemińska 2010). The commune's financial situation is shaped by a number of conditions, both external and internal - related to the given area. External determinants, e.g. the level of economic growth, unemployment, inflation rate, the socio-economic situation of neighbouring areas, are not directly influenced by local authorities. Conditions of the financial situation may be shaped by the area (e.g. location and size of local government units, available resources and natural values, investment attractiveness) and may also be independent of it (e.g. economic fluctuations in the country and in the world, the state of public finances, the scope of income control) (Dziekański, 2014).

The financial situation can be treated as one of the endogenous factors of socio-economic development, whose relatively high rating translates into improving the quality of life of the local community. The assessment of the financial situation allows you to manage the development of local government, as well as the tasks carried out. It can be prepared both for own needs and for external recipients (Filipiak, 2006). It allows determining not only the efficiency of units' functioning, i.e. the ability to meet their obligations, but also the possibility of raising the quality standard of services they provide to local communities (Dziekański, 2014). Income, expenses, taxation, and debt are a complex and multi-dimensional concept with different time frames. The elements are related; they must be analysed and evaluated together.

\section{The financial situation of rural communes in the Świętokrzyskie province (synthetic measure)}

The Świętokrzyskie region has an industrial and agricultural character with a high concentration of industry sectors related to the production and processing of metals, mining and processing of mineral resources and the production of foodstuffs. The main industries of the Świętokrzyskie region are: metallurgy, metal, machine, building materials, ceramic, foundry, and food. The economy of the Świętokrzyskie region is based on the mining industry in the field of building materials (limestone, dolomite, marl, gypsum, sandstone). The agricultural south is the base for the production of organic food (Jóźwiak, Jóźwiak, Strzyż, 2010).

Table 1 summarizes the values of the measure of the synthetic financial situation (TOPSIS) of rural communes in the Świętokrzyskie Voivodship in 2007, 2014, 2017 in subsequent quartile groups. The first quartile group includes the municipalities with the best financial standing, the last - the weakest. The value of the synthetic measure allowed dividing the communes of the Świętokrzyskie Province into 4 groups. Minor shifts in time and space can be observed between groups. In 2007, the measure of financial standing ranged from 
0.31 (Pierzchnica, the weakest unit, Kielce poviat) to 0.47 (Sitkówka-Nowiny, the best unit, Kielce poviat). In 2017, respectively, from 0.30 (Bliżyn, Skarżyski poviat) to 0.51 (Sitkówka-Nowiny). Group A communes, in the best financial situation, were also characterized by the highest average share of own income and taxes in the total income of units, developed industrial function. The units in which the traditional agricultural function dominates are in a weaker situation.

A synthetic measure based on distance in real space with Euclidean metrics allowed the division of rural communes in the Świętokrzyskie Province into 4 groups. The first quartile group includes the municipalities with the best financial standing (measure closer to 0 ), the last - the weakest (measure closer to 1 ). In 2007, the measure of financial standing ranged from 0.64 (Sitkówka-Nowiny, the best unit, Kielce poviat) to 0.80 (Tarłów, the weakest unit, Opatów poviat). In 2017 - from 0.56 (Sitkówka-Nowina, Kielce poviat) to 0.80 (Bliżyn, Skarżysko poviat). Group A units are characterized by the highest average share of revenues and local taxes and fees in total revenues.

Regardless of the method of aggregation of synthetic measure (TOPSIS or OE), Sitkówka-Nowiny, Masłów, Strawczyn, Zagnańsk, Solec-Zdrój found themselves high. The best units were strongly characterized by the mining and processing industry of mineral raw materials, the production of foodstuffs, agrotourism, spa and well-developed activities of the SME sector. At the other end were Klimontów, Pawłów, Radoszyce, Bieliny, Dwikozy, Iwaniska, and Bliżyn. The weakest units were characterized by agriculture, gardening, horticulture, agrotourism, industrial monoculture (cement), and dairy.

The financial situation of communes translates into disproportions in the scope of possibilities of satisfying local needs (Kopyściański, Rólczyński, 2014). It is correlated with the level of local development. Understood as a complex of quantitative and qualitative transformations within a given unit, referring to the standard of living of residents and the functioning of economic entities. Conditions of the financial situation may be shaped by, e.g. location and size of local government units, available resources and natural values, investment attractiveness, as well as, among others, economic fluctuations in the country and in the world, the state of public finances, the scope of income and expenditure power of local government units (Dziekański, 2014).

The box graph indicates data dispersion (Euczak, 2007). As shown in Figure 1, the variation in the synthetic financial measure is small, similar for the OE and TOPSIS measures. Outliers are Sitkówka-Nowiny (a unit with a strong industrial function, within the influence of the capital of the Kielce region, a developed SME sector).

Measures of spatial diversity indicate the relative stability of the dispersion of rural communes in the Świętokrzyskie voivodship in relation to their financial situation. In 2017, compared to 2007, the stability of the examined area according to the standard deviation (0.030.02 for TOPSIS; 0.03-0.03 for OE) can be indicated. The diversity coefficient is also indicated by the classic coefficient of variation, which in the analysed period was

Table 1

Classification of rural communes in the Świętokrzyskie province according to a synthetic measure, financial situation, and the level of their income for 2007, 2014, 2017 (TOPSIS)

\begin{tabular}{|c|c|c|c|c|c|}
\hline & 2007 & 2014 & \multicolumn{3}{|c|}{2017} \\
\hline & TOPSIS & TOPSIS & $\Delta$ TOPSIS & $\begin{array}{l}\text { own income / } \\
\text { total income }\end{array}$ & $\begin{array}{c}\text { Local taxes and fees / } \\
\text { total income } e^{1}\end{array}$ \\
\hline A & $\begin{array}{l}\text { Sitkówka-Nowiny } 0.47 \\
\text { Smyków } 0.45 \\
\text { Wojciechowice } 0.41 \\
\text { Bałtów } 0.37\end{array}$ & $\begin{array}{l}\text { Sitkówka-Nowiny } 0.46 \\
\text { Tuczępy } 0.43 \\
\text { Oleśnica } 0.41 \\
\text { Miedziana Góra gmina. }\end{array}$ & $\begin{array}{l}\text { Sitkówka-Nowiny } 0.51 \\
\text { Masłów } 0.39 \\
\text { Strawczyn } 0.39 \\
\text { Solec-Zdrój } 0.37\end{array}$ & 0.20 & 0.16 \\
\hline B & $\begin{array}{l}\text { Bieliny } 0.36 \\
\text { Moskorzew } 0.36 \\
\text { Pacanów } 0.36 \\
\text { Waśniów } 0.36 \\
\end{array}$ & $\begin{array}{l}\text { Radoszyce } 0.36 \\
\text { Secemin } 0.36 \\
\text { Solec-Zdrój } 0.36 \\
\text { Wiślica } 0.35 \\
\end{array}$ & $\begin{array}{l}\text { Mirzec } 0.36 \\
0.36 \text { Obrazów } \\
\text { Piekoszów } 0.36 \\
\text { Zagnańsk } 0.35 \\
\end{array}$ & 0.15 & 0.11 \\
\hline $\mathrm{C}$ & $\begin{array}{l}\text { Imielno } 0.34 \\
\text { Iwaniska } 0.34 \\
\text { Mirzec } 0.34 \\
\text { Słupia Konecka } 0.34\end{array}$ & \begin{tabular}{|l|} 
Klimontów 0.34 \\
Nowa Słupia 0.34 \\
Pacanów 0.34 \\
Zagnańsk 0.34 \\
\end{tabular} & $\begin{array}{l}\text { Baltów } 0.34 \\
\text { Kije } 0.34 \\
\text { Nowy Korczyn } 0.34 \\
\text { Rytwiany } 0.34\end{array}$ & 0,17 & 0,12 \\
\hline $\mathrm{D}$ & $\begin{array}{l}\text { Górno } 0.33 \\
\text { Sobków } 0.33 \\
\text { Tarłów } 0.33 \\
\text { Pierzchnica } 0.31\end{array}$ & \begin{tabular}{|l|} 
Bieliny 0.33 \\
Górno 0.33 \\
Piekoszów 0.33 \\
Iwaniska 0.3 \\
\end{tabular} & $\begin{array}{l}\text { Bieliny } 0.33 \\
\text { Dwikozy } 0.33 \\
\text { Iwaniska } 0.33 \\
\text { Bliżyn } 0.3\end{array}$ & 0,14 & 0,10 \\
\hline
\end{tabular}

In the first quartile group, there are communes with the highest values of $O E$ and $O M$ indicators and the highest values of $S K$ indicator, therefore, in the first quartile group you can find the best units, the last - the weakest ones due to financial situation; $\left({ }^{1}\right)$ is the average value in the quartile group. 
Vol. 5, No. 4, 2019

Baltic Journal of Economic Studies

Table 2

Classification of rural communes in the Świętokrzyskie province according to a synthetic measure, financial situation, and the level of their income for 2007, 2014, 2017 (TOPSIS)

\begin{tabular}{|c|c|c|c|c|c|}
\hline & 2007 & 2014 & \multicolumn{3}{|c|}{2017} \\
\hline & $\mathrm{OE}$ & $\mathrm{OE}$ & $\Delta \mathrm{OE}$ & $\begin{array}{c}\text { own income / total } \\
\text { income }^{1}\end{array}$ & $\begin{array}{c}\text { Local taxes and fees } \\
\text { total income }\end{array}$ \\
\hline A & $\begin{array}{l}\text { Sitkówka-Nowiny } 0.64 \\
\text { Smyków } 0.69 \\
\text { Wojciechowice } 0.7 \\
\text { Zagnańsk } 0.75\end{array}$ & $\begin{array}{l}\text { Sitkówka-Nowiny } 0.64 \\
\text { Tuczępy } 0.66 \\
\text { Szydłów } 0.7 \\
\text { Bałtów } 0.72\end{array}$ & $\begin{array}{l}\text { Sitkówka-Nowiny } 0.56 \\
\text { Masłów } 0.71 \\
\text { Strawczyn } 0.71 \\
\text { Zagnańsk } 0.75\end{array}$ & 0.20 & 0.16 \\
\hline B & \begin{tabular}{|l} 
Baćkowice 0.76 \\
Łagów 0.76 \\
Nowa Słupia 0.76 \\
Wilczyce 0.77
\end{tabular} & $\begin{array}{l}\text { Miedziana Góra } 0.73 \\
\text { Raków } 0.73 \\
\text { Wiślica } 0.73 \\
\text { Zagnańsk } 0.75\end{array}$ & $\begin{array}{l}\text { Bałtów } 0.76 \\
\text { Łagów } 0.76 \\
\text { Pacanów } 0.76 \\
\text { Raków } 0.76\end{array}$ & 0.16 & 0.13 \\
\hline $\mathrm{C}$ & $\begin{array}{l}\text { Górno } 0.78 \\
\text { Pacanów } 0.78 \\
\text { Solec-Zdrój } 0.78 \\
\text { Waśniów } 0.78\end{array}$ & $\begin{array}{l}\text { Klimontów } 0.76 \\
\text { Kluczewsko } 0.76 \\
\text { Pacanów } 0.76 \\
\text { Rytwiany } 0.76\end{array}$ & \begin{tabular}{|l} 
Górno 0.77 \\
Iwaniska 0.77 \\
Nowa Słupia 0.77 \\
Bieliny 0.78 \\
\end{tabular} & 0.14 & 0.10 \\
\hline D & $\begin{array}{l}\text { Iwaniska } 0.79 \\
\text { Mniów } 0.79 \\
\text { Moskorzew } 0.79 \\
\text { Tarłów } 0.8\end{array}$ & \begin{tabular}{|l|} 
Bieliny 0.77 \\
Górno 0.77 \\
Wilczyce 0.77 \\
Iwaniska 0.8
\end{tabular} & $\begin{array}{l}\text { Klimontów } 0.79 \\
\text { Pawłów } 0.79 \\
\text { Radoszyce } 0.79 \\
\text { Bliżyn } 0.8\end{array}$ & 0.11 & 0.09 \\
\hline
\end{tabular}

In the first quartile group, there are communes with the highest values of $O E$ and $O M$ indicators and the highest values of $S K$ indicator, therefore, in the first quartile group you can find the best units, the last - the weakest ones due to financial situation; $\left({ }^{1}\right)$ is the average value in the quartile group.

Source: own study based on data from RIO o / Kielce, BDL CSO

0.08-0.06 (TOPSIS) and 0.04-0.04 (OE), respectively. The range value for the analysed phenomenon indicates a slight increase in diversity (0.21-0.16 - TOPSIS and 0.24-0.16 for OE).

The Pearson correlation coefficient between the value of the TOPSIS and OE synthetic financial situation measure was in the years of 2014-2007 0.526 and in 2017-2014-0.582 (for OE) and 0.517 and 0.654 respectively (for TOPSIS). This may indicate a stable spatial diversity of units and a small degree of convergence. Tuczępy and Sitkówka-Nowiny belong to the group of distinctive entities (Figure 2). These units are leading areas for the Świętokrzyskie Province, connected in its central part.

The correlation coefficients in the case of the methods used indicate a high similarity of the results obtained in the relation of TOPSIS to OE. In 2007, Pearson's correlation coefficient was -0.861 , in $2017-0.878$, which may indicate convergence (Figure 3 ). This proves that each of the economic development indicators analysed indicates a similar classification of voivodships' development levels, and units could have reacted similarly to market changes.
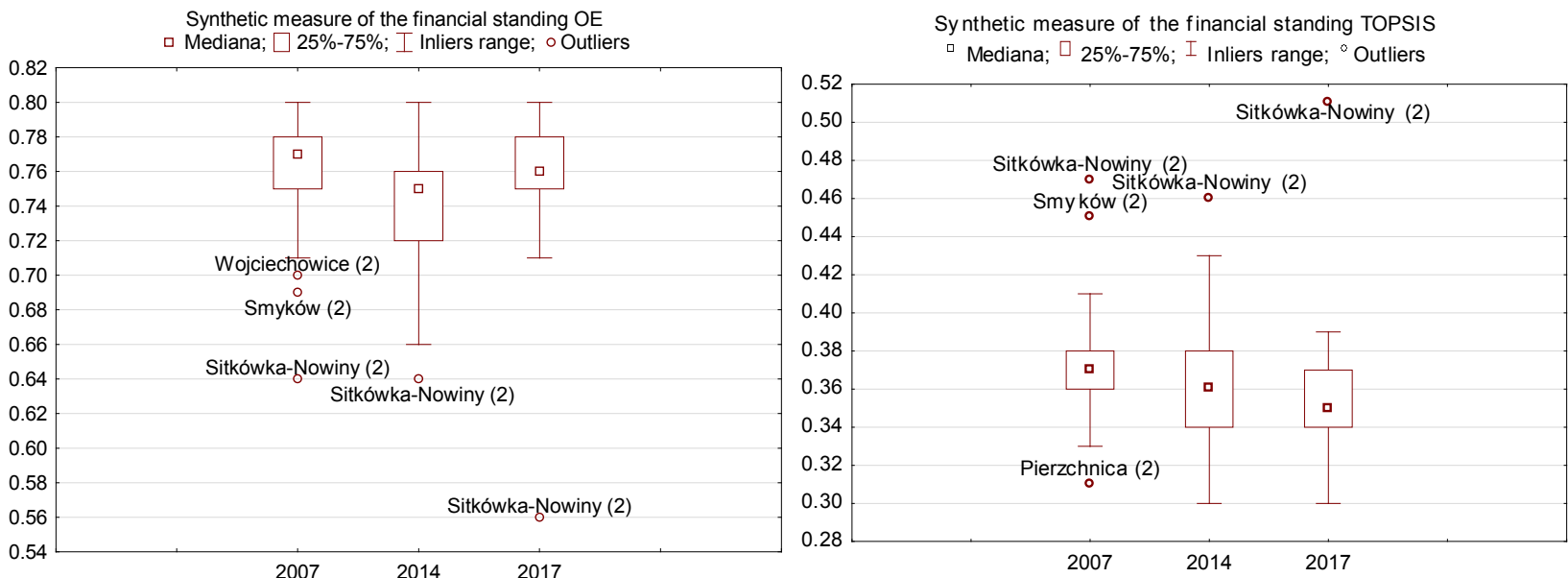

Figure 1. Graph of dispersion of rural communes in the Świętokrzyskie voivodship in the aspect of financial situation and development and development in 2007, 2014, 2017

Source: own study based on data from RIO o / Kielce, BDL CSO 
Table 3

Differentiation of synthetic measure, financial situation, and competitiveness

\begin{tabular}{|l|c|c|c|c|c|c|}
\hline \multirow{2}{*}{} & \multicolumn{2}{|c|}{ TOPSIS measure (financial standing) } & \multicolumn{3}{c|}{ EUKLIDES measure - finance } \\
\cline { 2 - 7 } & 2007 & 2014 & 2017 & 2007 & 2014 & 2017 \\
\hline merage & 0.37 & 0.36 & 0.36 & 0.76 & 0.74 & 0.76 \\
\hline median & 0.37 & 0.36 & 0.35 & 0.77 & 0.75 & 0.76 \\
\hline quartile deviation & 0.02 & 0.03 & 0.03 & 0.03 & 0.03 & 0.03 \\
\hline classic coefficient of variation & 0.37 & 0.36 & 0.36 & 0.77 & 0.74 & 0.77 \\
\hline positional coefficient of variation & 0.06 & 0.08 & 0.08 & 0.04 & 0.04 & 0.04 \\
\hline min & 1 & 1 & 1.01 & 0.99 & 0.99 & 1.01 \\
\hline max & 0.31 & 0.3 & 0.3 & 0.64 & 0.64 & 0.56 \\
\hline range & 0.47 & 0.46 & 0.51 & 0.8 & 0.8 & 0.8 \\
\hline quartile 1 & 0.16 & 0.16 & 0.21 & 0.16 & 0.16 & 0.24 \\
\hline quartile 2 & 0.36 & 0.34 & 0.34 & 0.75 & 0.72 & 0.75 \\
\hline quartile 3 & 0.37 & 0.36 & 0.35 & 0.77 & 0.75 & 0.76 \\
\hline quartile separation & 0.38 & 0.38 & 0.37 & 0.78 & 0.76 & 0.78 \\
\hline skewness & 0.02 & 0.04 & 0.03 & 0.03 & 0.04 & 0.03 \\
\hline measure of concentration-kurtosis & 1.58 & 0.7 & 2.19 & 1.69. & 0.71 & 3.62 \\
\hline
\end{tabular}

Source: own study based on data from RIO o / Kielce, BDL CSO
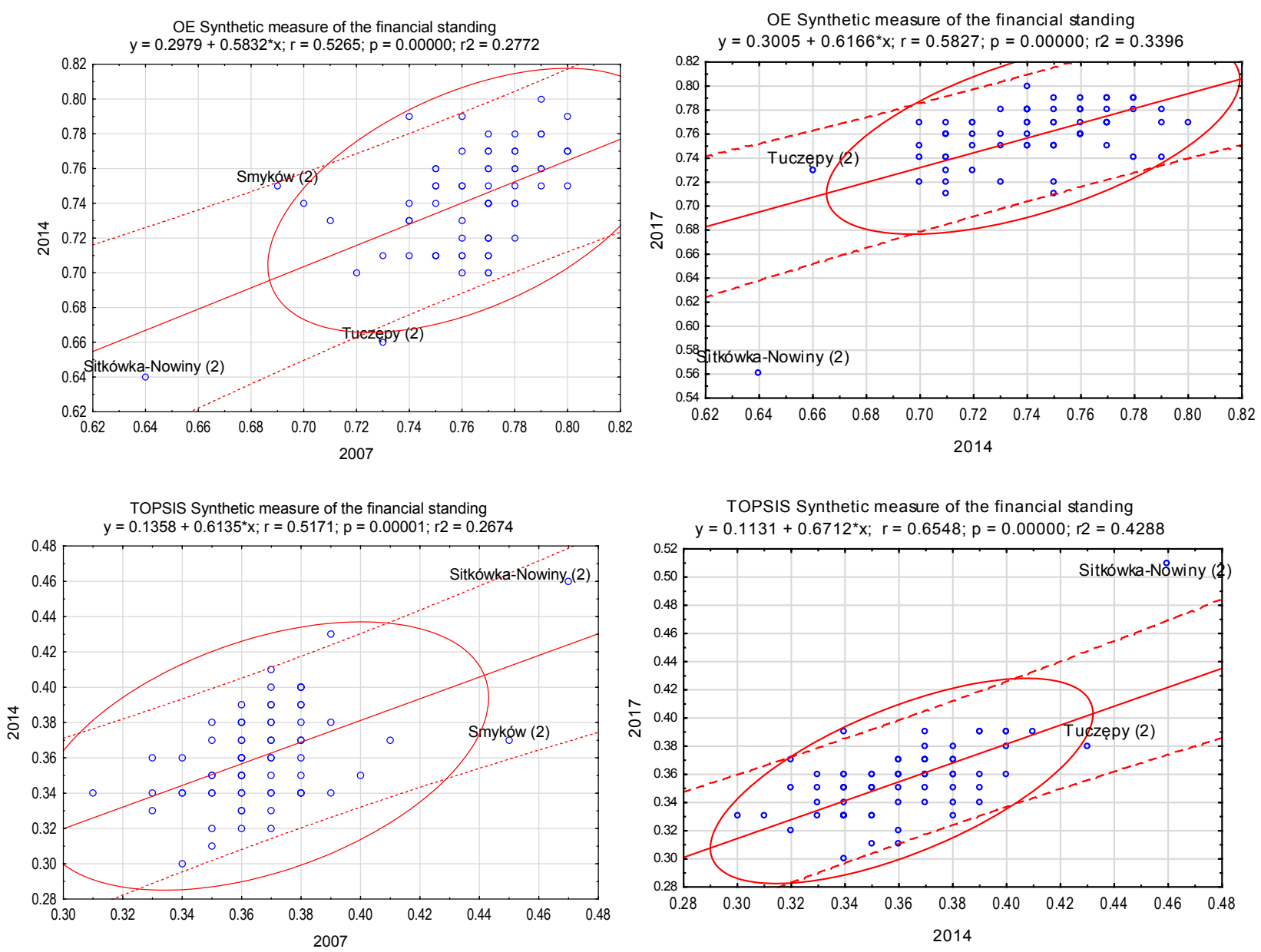

Figure 2. A scatter chart for measuring the synthetic financial situation with the matching line of rural communes in the Świętokrzyskie voivodship

Source: own study based on data from RIO o / Kielce, BDL CSO 

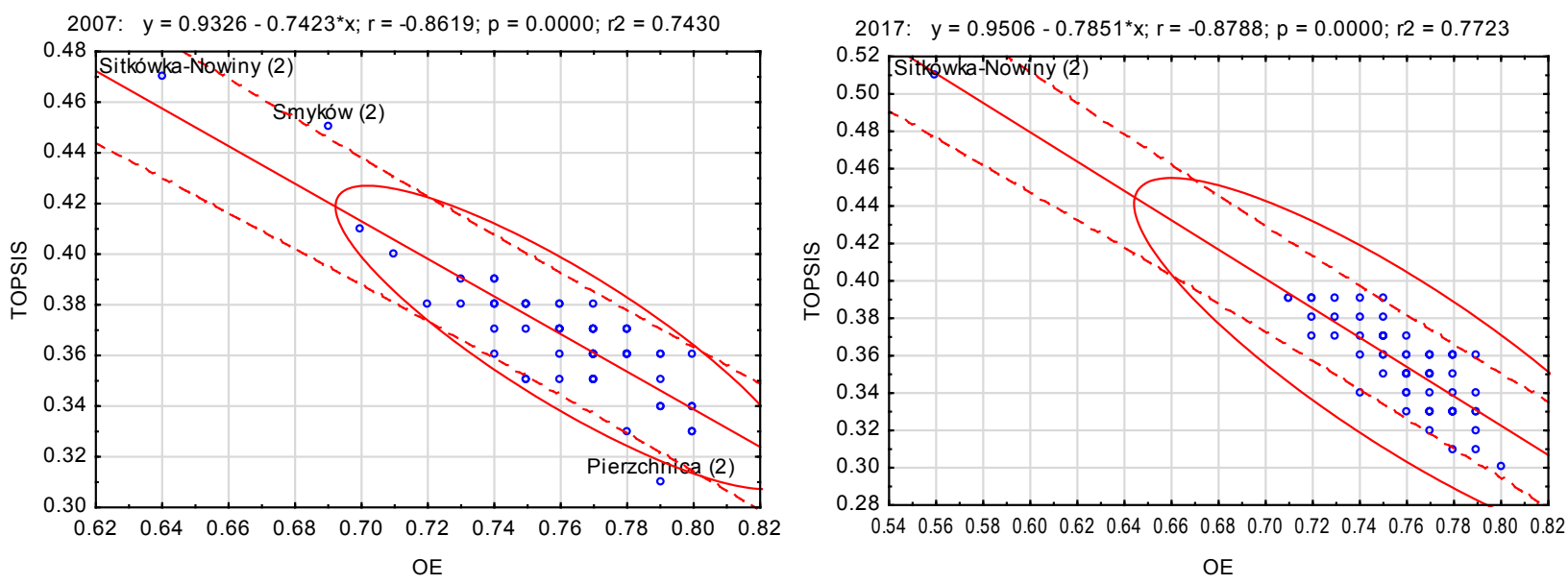

Figure 3. Scatter chart of the measure of the synthetic financial situation with the matching line of rural communes of the Świętokrzyskie voivodship in the relation OE to TOPSIS

Source: own study based on data from RIO o / Kielce, BDL CSO

When analysing the stability of the spatial diversity of the financial situation of rural communes in 2007-2017, correlation coefficients can be used. Its value between the TOPSIS measure and OE was -0.816 (Table 4), which may indicate that to a very similar extent they described the diversity of the financial situation of rural communes, and the spatial diversity of the studied phenomenon was stable. The level of the phenomenon under study was affected to the greatest extent by own income, taxes and local fees, as well as transfer and property (investment) expenses.

\section{Table 4}

Correlation of a measure of synthetic financial situation and competitiveness with their determinants

\begin{tabular}{|l|c|c|}
\hline & $\begin{array}{c}\text { TOPSIS financial } \\
\text { situation }\end{array}$ & $\begin{array}{c}\text { OE financial } \\
\text { situation }\end{array}$ \\
\hline Financial situation & -0.8167 & 1.0000 \\
\hline EU funds & .1254 & -0.3963 \\
\hline Own income & .6307 & -0.7548 \\
\hline Income from taxes and local fees & .5835 & -0.6639 \\
\hline Income from PIT and CIT & .0711 & -0.1743 \\
\hline Transfer income & -0.5331 & .6836 \\
\hline Operating surplus & .5054 & -0.3225 \\
\hline Debt & -0.3479 & -0.1663 \\
\hline Property (investment) expenses & .4539 & -0.6611 \\
\hline Current expenditure & -0.4537 & .6607 \\
\hline observations used 1-207 & & \\
\hline
\end{tabular}

Source: own study based on data from RIO o / Kielce, BDL CSO

The linear regression model indicating the explained variable and the explanatory variables takes the form:

f financial situation TOPSIS / OE $=\Sigma$

(EU funds, own income, local taxes and fees, income from PIT and CIT, transfer income, operating surplus, debt, property (investment) expenses, current expenses).
The results of the analysis for TOPSIS show that the presented regression model allows explaining $\mathrm{R}=0.708(\mathrm{r} 2=701)$ of variations of variables. High values of F (97.93) statistics and the corresponding level of probability $\mathrm{p}$ confirm the statistical significance of the linear model. The $t$-Student statistic value for the $\mathrm{p}$ parameter means that all parameters are statistically significant. The value of the determination coefficient (R2) indicates a good fit of the regression model to the data.

The results of the analysis for $\mathrm{OE}$ allow stating that the presented regression model allows explaining $\mathrm{R}=0.929(\mathrm{r} 2=0.927)$ of variable variations, indicating a very good fit of the regression model to the data. The high values of $\mathrm{F}$ (376.3) statistics and the corresponding level of probability $\mathrm{p}$ confirm the statistical significance of the linear model. The value of $\mathrm{t}$-Student statistics at the parameter means that all parameters are statistically significant.

\section{Conclusions}

In assessing the operation of municipalities, financial management is gaining importance. They shape the economic situation of the local government, the conditions for carrying out tasks, achieving the set goals. The interpretation of their amount and structure in individual years is not clear, e.g. due to loans taken out, EU funds obtained, investments are implemented and settled over several years. The income side determines the expenditure part, which confirms that both streams are related to each other.

The analysis of spatial data requires a multi-criteria approach, requires knowledge of the degree and specificity of the space diversity of the features of individual regions. Selected variables form territorial capital. It is characteristic for the region, individual for the area, different for individual communes, and should 
Table 5

KMNK estimation (observations 1-207 used; dependent variable: TOPSIS sf)

\begin{tabular}{|c|c|c|c|c|}
\hline & Rate & standard error & Student's t- & $\mathrm{p}$-value \\
\hline Constant & 0.289073 & 0.00344703 & 83.8614 & $<0.00001$ \\
\hline EU funds & $6.52791 \mathrm{e}-06$ & $6.56623 \mathrm{e}-06$ & .9942 & 0.32134 \\
\hline Own income & 0.109448 & 0.0265059 & 4.1292 & 0.00005 \\
\hline Income from taxes and local fees & 0.120443 & 0.0308867 & 3.8995 & 0.00013 \\
\hline Operating surplus & 0.265308 & 0.0243772 & 10.8835 & $<0.00001$ \\
\hline Property expenses & 0.0732006 & 0.0168209 & 4.3518 & 0.00002 \\
\hline
\end{tabular}

\begin{tabular}{|l|c|l|l|c|}
\hline Arithmetic mean of the dependent variable & 0.361159 & & Standard deviation of the dependent variable & 0.027139 \\
\hline Sum of squared residues & 0.044153 & & Residual Standard Error & 0.014821 \\
\hline Coefficient of Determination R-squared & 0.708986 & & Corrected R-squared & 0.701747 \\
\hline F $(5,201)$ & 97.93784 & & P-value for the F test & $6.16-52$ \\
\hline Logarithm of credibility & 581.1457 & & Akaike inform. crit. & -1150.291 \\
\hline Crit. Bayes. Schwarz & -1130.295 & & Crit. Hannan-Quinn & -1142.205 \\
\hline
\end{tabular}

Source: own study based on data from RIO o / Kielce, BDL CSO

Table 6

KMNK estimation (observations 1-207 used; dependent variable: OE SF)

\begin{tabular}{|c|c|c|c|c|}
\hline & Rate & standard error & Student's t- & p-value \\
\hline Constant & 0.679085 & 0.026747 & 25.3892 & $<0.00001$ \\
\hline EU funds & $-2.86753 e-05$ & $3.72707 \mathrm{e}-06$ & -7.6938 & $<0.00001$ \\
\hline Own income & -0.0859447 & 0.0165279 & -5.2000 & $<0.00001$ \\
\hline Income from taxes and local fees & -0.0203953 & 0.0287534 & -0.7093 & 0.47896 \\
\hline Income from PIT and CIT & 0.05996 & 0.0325459 & 1.8423 & 0.06692 \\
\hline Transfer income & 0.175085 & 0.0270775 & 6.4661 & $<0.00001$ \\
\hline Operating surplus & -0.180623 & 0.0137868 & -13.1012 & $<0.00001$ \\
\hline Property expenses & -0.134962 & 0.00951749 & -14.1804 & $<0.00001$ \\
\hline
\end{tabular}

\begin{tabular}{|l|c|l|l|c|}
\hline Arithmetic mean of the dependent variable & 0.754010 & & Standard deviation od the dependent variable & 0.031047 \\
\hline Sum of squared residues & 0.013948 & & Residual Standard Error & 0.008372 \\
\hline Coefficient of Determination R-squared & 0.929760 & & Corrected R-squared & 0.927289 \\
\hline F $(7,199)$ & 376.3058 & & P-value for the F test & $4.5 e-111$ \\
\hline Log credibility & 700.4136 & & Akaike inform. crit. & -1384.827 \\
\hline Crit. Bayes. Schwarz & -1358.166 & & Crit. Hannan-Quinn & -1374.046 \\
\hline
\end{tabular}

Source: own study based on data from RIO o / Kielce, BDL CSO

not be included in the same mathematical models averaging the variables.

Local government can carry out its tasks when it is equipped with stable and efficient sources of own income. The level and structure of budget revenues determine the investment activity of the commune. Therefore, finance is the basis for the implementation of public tasks and determines the conditions for local economic development.

Areas with a high level of financial standing were located mainly in the central area of the region and the influence of the region's capital (Sitkówka-Nowiny, Masłów, Strawczyn, Zagnańsk, Solec-Zdrój). The factors determining membership in the group were favourable position rents, very good financial standing and good infrastructure, mining and processing industry, mineral raw materials, food production, agrotourism, and health resorts.
At the other extreme of the distribution were areas with a low level of financial standing, which can be described as peripheral (Klimontów, Pawłów, Radoszyce, Bieliny, Dwikozy, Iwaniska, Bliżyn). This peripherality has a geographical dimension, expressed by its location relative to the centre of the region, and economic, being a derivative of adverse structural changes, as well as mixed, combining both dimensions. The indicated areas are characterized primarily by traditional agricultural functions.

In 2007, the financial standing measure (TOPSIS) ranged from 0.31 to 0.47 , in 2017 - from 0.30 to 0.51 . In 2007, the financial standing (OE) measure ranged from 0.64 to 0.80 , in 2017 - from 0.56 to 0.80 . Group A units are characterized by the highest average share of own revenues, as well as local taxes and fees in total revenues, developed industrial function. The units in which the traditional agricultural function dominates are in a weaker situation. 


\section{References:}

Churski, P., Borowczak, A., Dolata, M., Dominik, J., Hauke, J., Perdał, R., \& Konecka-Szydłowska, B. (2013). Czynniki rozwoju obszarów wzrostu i obszarów stagnacji gospodarczej w Polsce, Uniwersytet im. Adama Mickiewicza, Poznań.

Douglas, J. W., \& Gaddie, R. K. (2002). State rainy day funds and fiscal crises: Rainy day funds and the 1990-1991 recession revisited, Public Budgeting \& Finance, vol. 22. Retrieved from: https://doi:10.1111/1540-5850.00063 (accessed August, 01, 2019).

Dziekański, P. (2014). Analiza zróżnicowania kondycji finansowej powiatów województwa świętokrzyskiego, Nierówności Społeczne a Wzrost Gospodarczy, 40(4), pp. 42-54.

Dziekański, P. (2014). Koncepcja wskaźnika syntetycznego do oceny sytuacji finansowej powiatów, Research Papers of Wroctaw University of Economics, nr 329, pp. 98-108.

Dziekański, P. (2016). Spatial Differentiation of the Financial Condition of the Świętokrzyskie Voivodship Counties, Barometr Regionalny, Volume 14, nr 3.

Dziekański, P. (2017). Diversification synthetic indicator for evaluating the financial capacity of local government. The case of Polish voivodeships, Acta Universitatis Agriculturae Et Silviculturae Mendelianae Brunensis, Volume 65, Number 2.

Dziekański, P. (2018). Ocena efektywności funkcjonowania gmin województwa świętokrzyskiego w świetle ekonomii instytucjonalnej (analiza wielowymiarowa), Uniwersytet Jana Kochanowskiego w Kielcach, Kielce.

Dziekański, P., \& Pawlik, A. (2019). Intraregional diversification of the level of the financial situation of the poviats of Eastern Poland in relation to the development potential. Baltic Journal of Economic Studies. Vol. 5 , No. 3. doi: 10.30525/2256-0742/2019-5-3-1-8

Dziekański, P., \& Shaposhnykov, K. (2017). Zróżnicowanie przestrzenne sytuacji finansowej gmin a problem doboru zmiennych do badania, Studia i Materiały Miscellanea Oeconomicae R. 21, nr 3, t. 2, Myśl ekonomiczna, spółdzielczość, bankowość, samorządność, p. 161-171.

Filipiak, B. (2006). Analiza finansowa i jej znaczenie w zarządzaniu finansami [In:] Finanse samorządowe. Narzędzia, decyzje, procesy, ed. M. Dylewski, B. Filipiak, M. Gorzałczyńska-Koczkodaj. Wyd. Nauk. PWN, Warszawa, pp. 138-143.

Głowicka-Wołoszyn, R., \& Wysocki, F. (2016). Kondycja finansowa gmin wiejskich a źródła ich dochodów w województwie wielkopolskim, Roczniki Naukowe SERiA, tom XVIII, zeszyt 1.

Hendrick, R. (2004). Assessing and measuring the fiscal heath of local governments, Urban Affaires Review, vol. 40, No. 1. Retrieved from: https://dx.doi.org./10.1177/1078087404268076 (accessed August, 01, 2019).

Jóźwiak, M. A., Jóźwiak, M., \& Strzyż, M. (2010). Predyspozycje naturalne regionu świętokrzyskiego do rozwoju turystyki, Krajobraz a Turystyka, Prace Komisji Krajobrazu Kulturowego Nr 14, Komisja Krajobrazu Kulturowego PTG, Sosnowiec.

Klepacki, B., \& Kusto, B. Ocena kondycji finansowej gmin województwa świętokrzyskiego. Retrieved from: http://www.wne.sggw.pl/czasopisma/pdf/EIOGZ_2009_nr77_s127.pdf (accessed August, 05, 2019).

Kopyściański, T., \& Rólczyński, T. (2014). Analiza wskaźników opisujących sytuację finansową powiatów w województwie dolnośląskim w latach 2006-2012, Studia Ekonomiczne, Nr 206, Wyd. UE w Katowicach, Katowice, pp. 61-62.

Kukuła, K. (2014). Regionalne zróżnicowanie stopnia zanieczyszczenia środowiska w Polsce a gospodarka odpadami, Przedsiębiorczość i Zarządzanie, t. 15, z. 8, cz. 1, Wybrane problemy zarządzania rozwojem regionalnym, pp. 83-198.

Łuczak, A., \& Wysocki, F. (2012). Zastosowanie uogólnionej miary odległości GDM oraz metody TOPSIS do oceny poziomu rozwoju społeczno-gospodarczego powiatów województwa wielkopolskiego, Przegląd Statystyczny Numer Specjalny 2.

Łuczak, J. (2007). Metody i techniki zarządzania jakością, Quality Progress, Poznań.

Malina, A. (2004). Wielowymiarowa analiza przestrzennego zróżnicowania struktury gospodarki Polski według województw, Wyd. AE w Krakowie, Kraków, pp. 96-97.

Młodak, A. (2006). Analiza taksonomiczna w statystyce regionalnej, Centrum Doradztwa i Informacji Difin, Warszawa 2006.

Ossowska, L., \& Ziemińska, A. (2010). Kondycja finansowa gmin wiejskich i miejsko-wiejskich województwa pomorskiego, Journal of Agribusiness and Rural Development, 4(18), Uniwersytet Przyrodniczy w Poznaniu, pp. 73-74.

Patrzałek, L. (2010). Finanse samorządu terytorialnego a koncepcje rozwoju lokalnego i regionalnego, Prace Naukowe Uniwersytetu Ekonomicznego we Wrocławiu 112, Finanse publiczne, pp. 549-556.

Poczta, J. (2012). Renta położenia jako warunek powodzenia działalności agroturystycznej oraz kształtowania produktów turystycznych na obszarach wiejskich, Zeszyty Naukowe Uniwersytetu Szczecińskiego, nr 701, Ekonomiczne Problemy Usług, nr 86, pp. 301-315.

Prusek, A., \& Kudełko, J. (2009). Analiza i ocena zróżnicowania poziomu rozwoju polskich regionów w latach 2000-2006 w świetle polityki spójności, Prace Naukowe Uniwersytetu Ekonomicznego we Wrocławiu, nr 46. 
Ritonga, I. T. (2014). Modelling local government financial conditions in Indonesia, Victoria University Melbourne [for] M. Stanny, W. Strzelczyk, 2017, Pomiar kondycji finansowej jednostek samorządu lokalnego - kwerenda międzynarodowa, Nierówności Społeczne a Wzrost Gospodarczy, nr 49(1).

Rosner, A., \& Stanny, M. (2014). Monitoring rozwoju obszarów wiejskich. Etap I. Przestrzenne zróżnicowanie poziomu rozwoju społeczno-gospodarczego obszarów wiejskich w 2010 roku, IRWiR PAN, Warszawa, p. 33.

Rynio, D. (2013). Kształtowanie nowej polityki regionalnej Polski w warunkach globalizacji i integracji, Monografie i Opracowania Uniwersytetu Ekonomicznego we Wrocławiu, nr 240, 357 p.

Satoła, Ł. (2015). Kondycja finansowa gmin w warunkach zmiennej koniunktury gospodarczej, Journal Agribusiness and Rural Development, 1(35), pp. 115-123.

Sobczyk, A. (2010). Rozwój lokalny - wybrane problemy finansowania, Zeszyty Naukowe SGGW, Ekonomika i Organizacja Gospodarki Żywnościowej 81, Warszawa, pp. 125-136.

Stanny, M. (2013). Przestrzenne zróżnicowanie rozwoju obszarów wiejskich w Polsce, IRWiR PAN, Warszawa.

Trojak, M., \& Tokarski, T. (red.) (2013). Statystyczna analiza przestrzennego zróżnicowania rozwoju ekonomicznego i społecznego Polski, Wyd. UJ, Kraków.

Wysocki, F. (1996). Metody statystycznej analizy wielowymiarowej w rozpoznawaniu typów struktury przestrzennej rolnictwa, Roczniki AR w Poznaniu, seria: Rozprawy Naukowe, z. 266, Poznań.

Wysocki, F. (2010). Metody taksonomiczne w rozpoznaniu typów ekonomicznych rolnictwa i obszarów wiejskich, Wyd. UP w Poznaniu, Poznań.

Wysocki, F., Lira, J. (2005). Statystyka opisowa, Wyd. AR im. Augusta Cieszkowskiego w Poznaniu, Poznań.

Zakrzewska-Półtorak, A. (2011). Zasoby endogeniczne jako czynnik rozwoju lokalnego i regionalnego. Studium przypadków wybranych gmin województwa dolnośląskiego, Prace Naukowe Uniwersytetu Ekonomicznego we Wrocławiu, nr 152, pp. 579-588.

Zalewski, W. (2012). Zastosowanie metody TOPSIS do oceny kondycji finansowej spółek dystrybucyjnych energii elektrycznej, Ekonomia i Zarządzanie, 4/2012, pp. 137-145. 